\title{
A CRITIQUE OF THE ODIOUS DEBT DOCTRINE
}

\author{
AlBerT H. CHOI* \\ ERIC A. POSNER**
}

\section{INTRODUCTION}

The western liberal states have practical and humanitarian interests in preventing other states from being taken over by dictators and in encouraging democratic reform in existing dictatorships. Dictatorships often mistreat and impoverish their own citizens and commit atrocities. Dictatorships also produce refugee crises, fight with their neighbors, and provide havens for terrorists. Because dictatorships rarely enjoy the broad support of their own citizens, they are vulnerable to insurgencies and civil war.

Yet liberal states have taken an ambivalent attitude toward dictatorships. On the one hand, governments of liberal states make clear that they disapprove of dictatorships and usually subject them to diplomatic pressure. Particularly bad dictatorships may be subject to sanctions of various sorts, including economic sanctions; and some are subverted or attacked. Recent examples include the invasion of Iraq, the intervention in Kosovo, the sanctions imposed on Sudan, and the long-running sanctions on Cuba. Only in rare instances are dictators prosecuted for their crimes.

On the other hand, western governments also frequently cooperate with dictatorships. They authorize trade, including the sale of weapons; they authorize private investment; they even give foreign aid to the dictatorships. Indeed, cooperation is the more common practice. China, Russia, Egypt, Saudi Arabia, and many other authoritarian states that routinely abuse their citizens are permitted to join international organizations, enjoy liberal trading relationships with the western powers, and in some cases receive foreign aid. During the Cold War, the United States and its allies supported dictatorships that took a hard line against the Soviet Union.

This ambivalence reflects the conflicting interests of western states. They have humanitarian and strategic interests in encouraging democracy and respect

\footnotetext{
Copyright (C) 2007 by Albert H. Choi and Eric A. Posner.

This article is also available at http://www.law.duke.edu/journals/lcp.

* Associate Professor of Law, University of Virginia Law School.

** Kirkland \& Ellis Professor of Law, University of Chicago Law School.

Thanks to Stephania Bonilla, Mitu Gulati, and Paul Stephan for their helpful comments.
} 
for human rights; but they also have strong strategic interests in trading, entering military alliances, and in other ways cooperating with dictatorships, especially powerful dictatorships. Indeed, even humanitarian reasons can be given for such cooperation; it is often argued that engagement is more likely to lead to reform than isolation, and in any event it is often the case that western powers need the assistance of dictatorships in order to perform humanitarian missions. For example, China and Russia wield vetoes on the United Nations Security Council, so any lawful humanitarian military intervention needs their permission, which they are likely to withhold if they believe that western states seek to isolate them.

These complexities suggest that liberal states will usually have to take a flexible approach to dictatorships-constantly adjusting the degree of cooperation or isolation in response to events. States need to take account not only of liberalizing tendencies, which they will want to reward; they also have to keep in mind the extent to which a dictatorship may become more or less important for its strategic interests. A government that tries to isolate Syria because of its terrorist ties might end up needing to cooperate with it in order to resolve the conflict in Iraq. ${ }^{3}$ States also worry that the sanctions they impose might fail to dislodge the dictator while imposing hardship on the public- the opposite of their purpose. The sanctions on Iraq from 1993 to 2003 had just this effect. ${ }^{2}$ It is thus not surprising that empirical studies of sanction regimes suggest that they usually fail to accomplish the ends of the states that imposed the sanctions. ${ }^{3}$

Frustrated with the limited success of sanction regimes, some scholars and advocates argue that sanctions should be legalized - that is, sanctions should be required by international law when certain conditions are satisfied, rather than imposed episodically on the basis of political considerations. Current interest focuses on the odious debt doctrine, which provides that a successor regime is not responsible for paying the debts of a prior regime if those debts were incurred by an authoritarian government and used to enrich it officials rather than to benefit the public. ${ }^{4}$ The legal status of the doctrine is controversial, but it has many advocates.

1. See Congressionally appointed Panel, The Iraq Study Group Report: The Way ForWARD - A NEW APPROACH 37 (2006) (JAMES A. BAKER, III \& LEE H. HAMILTON, Co-CHAIRS) (recommending that the United States "engage directly with Iran and Syria in order to try to gain their commitment to constructive policies toward Iraq and other regional issues").

2. See David Cortright \& George A. Lopez, Are Sanctions Just? The Problematic Case of Iraq, 52 J. INT'L AFFAIRS 33 (1999).

3. See Gary C. Hufbauer et al., Economic Sanctions Reconsidered: History and CURRENT POLICY 92-93 (2d ed. 1990) (finding that, based on their criteria, sanctions were successful in about thirty-four percent of 116 postwar cases).

4. For recent discussions of the doctrine and its history, see, for example, Lee. C. Buchheit, G. Mitu Gulati \& Robert B. Thompson, The Dilemma of Odious Debts, 56 DUKE L.J. 1201 (2007); Adam Feibelman, Equitable Subordination, Fraudulent Transfer, and Sovereign Debt, 70 LAW \& CONTEMP. PROBS. (forthcoming Autumn 2007).

5. See, e.g., Patricia Adams, Odious Debts: Loose Lending, Corruption, And the THIRD WORLD's ENVIRONMENTAL LEGACY (1991); Seema Jayachandran \& Michael Kremer, Odious 
It should be clear that the odious debt doctrine is not meant as an overall solution to the problem of how to treat dictators. It does not interfere with trade or travel or other things that dictators might care about; it interferes only with lending. Thus, one puzzle raised by the doctrine is why lending, rather than trade, should be subject to legal regulation and whether there is any point in restricting cooperation along one dimension while maintaining it along others. The odious debt doctrine also does not address the benefits of cooperating with dictators; it does not excuse a dictator who arrests terrorists at the request of western governments, who takes in refugees from a conflict in a bordering country, or who provides assistance in a humanitarian intervention.

For these and related reasons, support for the odious debt doctrine at this point is premature and unwise. As this article shows, it is unclear whether the doctrine will improve the welfare of the population that might be subject to a dictatorship. Although a selective application of the doctrine can improve welfare in principle, it is unlikely such selective application would be practicable. If incorporated into international law, there is a danger that the odious debt doctrine would do more harm than good.

\section{II}

\section{THE Normative CASE FOR THE OdIOUS DEBT DOCTRINE}

Defenders of the odious debt doctrine often rest their case on the simple and apparently morally compelling claim that an impoverished population that has recently overthrown a dictator should not have to pay sovereign debt incurred by the dictator to pay for personal gain. But the well-being of the postdictatorship population cannot be taken in isolation; one needs to consider the likely impact of the doctrine on the well-being of the population before the dictator is overthrown and on the well-being of populations who are never able to escape a dictatorship. To do this, one needs to take an ex ante perspective, comparing the well-being of affected populations in a world in which the doctrine exists and a world in which it does not.

The conventional ex ante defense of the rule does just this. Suppose creditors know they cannot collect if the money lent to a dictator is used to finance his private consumption. Creditors will respond to the rule by declining to make such loans or by charging a higher interest rate. As a result, dictators will not be able to borrow for private consumption, and more money will be left for future generations of the population. As the dictator is just a single person with a lot of money already, who therefore obtains a small marginal gain from

Debt, 96 AMER. ECON. REV. 82 (2006) (arguing that loan sanctions would be more effective than trade sanctions); ASHFAQ KHALFAn, JeFF King \& BRIAN ThOMAs, CTR. FOR INT'L Sustainable DeV. LAw, ADVANCING THE ODIOUs DEBT DOCTRINE (Mar. 2003), http://www.odiousdebts.org/ odiousdebts/publications/Advancing_the_Odious_Debt_Doctrine.pdf. Some authors reject the doctrine but support its premises and seek other legal means for operationalizing them. See, e.g., Buchheit et al., supra note 4 (describing domestic legal analogies); Feibelman, supra note 4 (advocating a contractual mechanism). 
an additional dollar, and as the future public is poor and thus will value an additional dollar a lot, the restriction on lending should, by transferring wealth from the dictator to the future public, produce a welfare gain. Of course, not all dictators start off as wealthy people, and some dictators are just figureheads of groups, but the same point holds: the power-holders are, in general, much wealthier than the public.

Potentially of even greater importance, would-be dictators may be deterred from taking power if they anticipate that they will not be able to borrow for personal gain even though they control the government. If so, the odious debt doctrine will, in the long run, reduce the number of dictatorships and in this way improve the well-being of populations that would be subject to dictatorships but for the deterrent effect of the doctrine. Meanwhile, the loss of the lending opportunity to creditors, most of which are firms with relatively wealthy shareholders, is likely to have a small impact on utility. In the short run, profits might be somewhat smaller, but the international lending market is highly liquid, and investors should be able to find nearly as good opportunities. In the long run, lending opportunities will not be reduced because creditors can lend to the additional states that do not have dictatorships as a result of the odious debt doctrine. This argument in favor of restrictions on lending is no different from an argument in favor of any other kind of sanction, from economic to military, and thus whether it is true or not depends on the basic considerations for and against sanctioning. ${ }^{6}$

\section{III}

\section{A Model of THE Odious DeBt DoctRine}

The argument described above is excessively optimistic; it overlooks significant practical difficulties. The following model of odious debt financing addresses some of these difficulties. Of particular interest here is whether a dictator, who attempts to stay in power for a long period and to maximize his personal gain, will borrow from abroad for immediate consumption or for deferred consumption through longer-term investments. This model also analyzes how the odious debt doctrine will affect the dictator's choice regarding short- or long-term loans and how that, in turn, will affect the public. The model will demonstrate that while the dictator will prefer the lending regime without the doctrine, whether the public will benefit from the doctrine is unclear and depends on complex factors.

6. This point is obvious but is mentioned because some commentators might be read to say otherwise. See, e.g., Jayachandran \& Kremer, supra note 5, at 88 ("[L]oan sanctions make the population better off in future periods [than trade sanctions do] since it has no debt repayment to make."). However, Jayachandran and Kremer acknowledge in a footnote that this is false if the dictator can trade nonrenewable resources, $i d$. at $88 \mathrm{n} .7$, which in our view is fatal to their claim. See discussion infra Part III.C. 


\section{A. The Model}

There are four periods in the model. At $\mathrm{t}=1$, a potential dictator decides whether to stage a coup. Although the cost of staging a coup is not explicitly modeled here, it is assumed that it is costly and the dictator's decision depends on his expected utility from success. If he comes into power at $\mathrm{t}=2$, he borrows money from abroad and spends either on private consumption or on a quasipublic investment. He can also decide not to borrow at all, in which case he will rely only on the resources provided by the country. Borrowing from abroad is accompanied by a promise to pay back at $\mathrm{t}=4$. At $\mathrm{t}=3$, the dictator is overthrown with some positive probability. It is assumed that it is costly for the public to overthrow the dictator and the public's decision depends, in part, on its expected gain from overthrowing him. At $\mathrm{t}=4$, if the dictator was overthrown at $\mathrm{t}=3$, then a representative government either repudiates the debt that was borrowed by the dictator in $\mathrm{t}=2$ or pays it back, depending on whether the odious debt doctrine is in place or not. If the dictator is not overthrown at $t=3$, the dictator must pay back the loan he borrowed at $\mathrm{t}=2$. It is also assumed that if the odious debt doctrine is not in place, both the representative government and the dictator will pay back the money at $\mathrm{t}=4$ because they are concerned about their future borrowing capacity.

If the dictator does not come to power at $\mathrm{t}=1$, a representative government will not borrow at $\mathrm{t}=2$ and instead will consume all domestically available resources. The country will behave in the same fashion at $t=3$ with or without a dictator. At $\mathrm{t}=4$, there will be no debt to pay in the absence of a coup at $\mathrm{t}=1$.

Suppose at $\mathrm{t}=2$ and $\mathrm{t}=4$, the country generates a cash flow of $r>0$ per period that the dictator can extract for his own benefit at $\mathrm{t}=2$ or use to repay the debt at $\mathrm{t}=4$. At $\mathrm{t}=2$, assume the dictator can borrow amount $d$ from abroad. For the sake of simplicity, there is no time discount, and the interest rate that is charged by the competitive international banking industry is zero. Also assume the probability $(p)$ of overthrowing the dictator at $\mathrm{t}=3$ is $p_{1}$ if the odious debt doctrine is in place, and $p_{2}$ if the doctrine is not in place, where the probabilities are strictly between zero and one. Finally, the country generates enough cash flow to satisfy the debt at $\mathrm{t}=4: r>d$.

After the dictator comes into power at $\mathrm{t}=1$, he cares about his expected utility, given by $c_{2}+(1-p) \cdot c_{4}$, where $c_{2}$ and $c_{4}$ are the amounts of resources the dictator consumes in periods two and four. The level of consumption will depend on the amount of resources he extracts from the public, money borrowed from abroad, and the cash flow generated by a quasi-public investment. The public's utility is given by $u\left(b_{2}\right)+p \cdot u\left(b_{4}\right)+(1-p) \cdot u\left(b_{4}^{\prime}\right)$, where $b_{2}$,

7. This model ends at $t=4$, but we can imagine that this is just one stage in a repeated game framework. For instance, if the dictator is not overthrown at $t=3$, we can think of the fourth period as being equivalent to the second, whereas if the dictator is overthrown at $t=3$, we can assume that the game starts again from $\mathrm{t}=1$. While a repeated game can support many different types of equilibrium, one possibility is for the government to pay back at $\mathrm{t}=4$ and the lending institutions to lend again in the future. 
$b_{4}$, and $b_{4}{ }_{4}$ are the levels of consumption the public enjoy in period two, four with overthrow, and four without overthrow, respectively. It is assumed that if the dictator takes away $\$ 1$ from the public, the loss of utility to the public is larger than the utility the dictator gains; that is, $u^{\prime}>1$. Also, assume that $u^{\prime}$ is constant and $u(0)=0$. If the (potential) dictator does not come into power at $\mathrm{t}=1$, it is assumed that his utility is zero, and the public consumes the cash flow $r$ in each period: its utility is $u(r)+u(r)$.

\section{The Case of No Borrowing}

Suppose the dictator does not borrow. Conditional on being in power, the dictator will take away the entire cash flow $r$ in $\mathrm{t}=2$ and again in $\mathrm{t}=4$ for his private consumption. The public will have something for its own consumption only when the dictator is out of power in $\mathrm{t}=4$ so the public, by overthrowing the dictator at $\mathrm{t}=3$, expects to gain $u(r)$. Overthrowing the dictator is costly and an attempt to overthrow may not always be successful, and this will lead to some probability $p$ that determines whether the dictator will be in power. The dictator's utility, therefore, is $r+(1-p) \cdot r$, and the public's utility is $p \cdot u(r)$. At $\mathrm{t}=1$, a potential dictator will compare the expected benefit $r+(1-p) \cdot r$ with the cost of staging a coup, and this will determine the probability of the dictator coming into power: $q$.

\section{Borrowing for Pure Consumption}

Suppose the dictator is in power and borrows $d$ at $\mathrm{t}=2$ for personal consumption. Consumption does not generate any future cash flow. How much the international banking community will charge for this loan will depend on the existence of the odious debt doctrine. If the subsequent government at $t=4$ can (and will) repudiate the debt under the odious debt doctrine, and since the banks can recover their lending only under the dictatorial regime, they will demand, as repayment at $\mathrm{t}=4, d /\left(1-p_{1}\right)$. If the subsequent government must pay back the loan, they will demand $d$.

Without the odious debt doctrine, the dictator will borrow $d$ at $t=2$, consume $r+d$ at $\mathrm{t}=2$, and repay $d$ at $\mathrm{t}=4$ if he is in power. At period four, he will again extract everything for his personal consumption. His utility, therefore, is $(r+d)+\left(1-p_{2}\right)(r-d)$, which is equal to $r+\left(1-p_{2}\right) \cdot r+p_{2} \cdot d$. The public receives no money at $\mathrm{t}=2$ but is saddled with the obligation of repayment after the dictator has been overthrown. The public's utility is $p_{2} \cdot u(r-d)$. If the doctrine is in place, the banks can recover from the dictator only if the dictator is not overthrown at $\mathrm{t}=3$. The dictator's utility is $(r+d)+\left(1-p_{1}\right)\left(r-d /\left(1-p_{1}\right)\right)$, which is equal to $r+\left(1-p_{1}\right) \cdot r$. The public enjoys $p_{1} \cdot u(r)$. Not surprisingly, the public enjoys a higher utility level with the odious debt doctrine, and the dictator enjoys higher utility without the doctrine.

When the odious debt doctrine is not in place, the dictator's borrowing from abroad for personal consumption imposes a negative externality onto the future government, because the future government must bear the burden of repayment. The difference in the two cases is the amount of this externality: 
approximately $p_{2} \cdot u(d)$. What the odious debt doctrine does, then, is to make the dictator internalize this negative externality by paying back more in case he stays in power. In some cases, the size of the repayment demand will be large enough, that is, $d /\left(1-p_{1}\right)>r$, to prevent the dictator from borrowing for personal consumption altogether.

Now, it is easy to understand what the potential problem of the odious debt doctrine is. Because the doctrine causes the dictator to internalize only the negative externality (by having to pay back more in case he stays in power), any project that has some positive externality for the public will become less attractive for the dictator. The banking community does not care about the amount of positive externality that a project (at $t=2$ ) can impose onto the public. It cares only about repayment. This can be illustrated with the following example.

\section{Borrowing for a Quasi-Public Investment}

Suppose the dictator can borrow $d$ at $\mathrm{t}=2$ to implement a project. The project generates a cash flow of $x$ and also a public benefit of $u(y)$ in $\mathrm{t}=4$. It will be assumed that the dictator can take the entire $x$ away but not $u(y)$. Think of $x$ as the additional cash flow and $u(y)$ as some intangible consumption benefit that accrues to the public. For the project to be worthwhile for the dictator, assume that $x>d$. On the other hand, $u(y)$ can be greater than or equal to zero. As an example, the project might be building infrastructure (like drilling an oil well, digging a mine, building a road, constructing a power station) that generates cash flow that the dictator can grab but also generates some benefit for the public. This model allows for the possibility that the investment only generates cash flow that the dictator can grab: $u(y)=0$. Meanwhile, this model assumes that the initial revenue $r$ will be consumed by the dictator. ${ }^{8}$

Without the odious debt doctrine, the banks will demand $d$ for repayment at $\mathrm{t}=4$. Conditional on implementing the project, the dictator will enjoy the utility of $r+\left(1-p_{2}\right) \cdot(r+x-d)$. At $\mathrm{t}=2$, the dictator will extract the entire $r$ for personal consumption and borrow $d$ to implement the project. At $\mathrm{t}=4$, once the project generates the cash flow of $x$, the dictator takes all of it while paying back the $d$ that was borrowed. The public will enjoy the utility of $u(y)+p_{2} \cdot u(r+x-d)$. At $\mathrm{t}=2$, the public gets no money. But the project provides the public the utility of $u(y)$ as well as the added benefit of $u(x-d)$ in case the dictator is overthrown.

With the odious debt doctrine, assume that the international community cannot tell whether the dictator has spent the borrowed money on a quasipublic project or on purely personal consumption. After all, the proponent may argue that since the dictator's motive for borrowing is for investment that

8. Although the dictator can use the existing resources $(r)$ to finance the project, borrowing from abroad will be more beneficial for him since it leaves more for his consumption. Borrowing becomes even more attractive if the repayment obligation is partly borne by the future government. 
generates more wealth for his own pocket in the future-especially when $u(y)=0$ - the doctrine should still apply to this type of spending. ${ }^{9}$ Now, for borrowing $d$ at $\mathrm{t}=2$, the bank demands $d /\left(1-p_{1}\right)$ at $\mathrm{t}=4$, assuming the dictator has not been thrown out. The dictator will enjoy the utility of $r+\left(1-p_{1}\right)\left(r+x-d /\left(1-p_{1}\right)\right)$. The public will enjoy the utility of $u(y)+p_{1} \cdot u(r+x)$. The difference from the previous example is that, whereas the dictator gets to enjoy the cash flow benefit of the project only with probability $\left(1-p_{1}\right)$, he has to bear the entire borrowing cost. The project generates a positive externality for the public.

\section{Choice Among Investment, Consumption, and No Borrowing}

The choice the dictator faces at $\mathrm{t}=2$ is to borrow and invest in the project, to borrow for purely personal consumption, or not to borrow at all. When the odious debt doctrine is in place, by not borrowing or borrowing for personal consumption, the dictator realizes the expected utility of $r+\left(1-p_{1}\right) \cdot r$, and the public receives an expected utility of $p_{1} \cdot u(r)$. If he were to borrow to invest in the project, he gets an expected utility of $r+\left(1-p_{1}\right)\left(r+x-d /\left(1-p_{1}\right)\right)$, while the public receives an expected utility of $u(y)+p_{1} \cdot u(x+r)$. Hence, when the dictator is deciding whether to invest or to consume what he borrows, he will borrow to invest only when $x-d /\left(1-p_{1}\right)>0$ or $\left(1-p_{1}\right) x>d$.

\begin{tabular}{|c|c|c|}
\hline & \multicolumn{2}{|c|}{ With the odious debt doctrine } \\
\hline & Dictator's utility & Public's utility \\
\hline No borrowing ${ }^{10}$ & $r+\left(1-p_{1}\right) \cdot r$ & $p \cdot u(r)$ \\
\hline $\begin{array}{l}\text { Personal } \\
\text { consumption }\end{array}$ & $r+\left(1-p_{1}\right) \cdot r$ & $p_{1} \cdot u(r)$ \\
\hline Quasi-public project & $R+\left(1-p_{1}\right)\left(r+x-d /\left(1-p_{1}\right)\right.$ & $u(y)+p_{1} \cdot u(x+r)$ \\
\hline
\end{tabular}

Without the odious debt doctrine, between investing in the project and not borrowing at all, the dictator will invest. By investing, he realizes the utility of $r+\left(1-p_{2}\right)(r+x-d)$, while the public enjoys $u(y)+p_{2} \cdot u(r+x-d)$. If he were to borrow for personal consumption, on the other hand, he gets $r+\left(1-p_{2}\right) \cdot r+p_{2} \cdot d$ and the public receives $p_{2} \cdot u(r-d)$. Between borrowing to invest and borrowing to consume, if $\left(1-p_{2}\right)(x-d)>p_{2} \cdot d$, he will invest, but if $\left(1-p_{2}\right)(x-d)<p_{2} \cdot d$, he will borrow for personal consumption. The comparison is between the magnitude of the negative externality he can impose on the public for consumption borrowing versus the amount of benefit he receives from investing in the project.

9. This is the view of many supporters of the doctrine. See sources cited infra note 15.

10. We can make the probability of overthrowing the dictator independent of the odious debt regime when the dictator does not borrow, but this will not change the substantive results of the paper. 


\begin{tabular}{|l|l|l|}
\hline & \multicolumn{2}{|l|}{ Without the odious debt doctrine } \\
\hline & Dictator's utility & Public's utility \\
\hline No borrowing & $r+\left(1-p_{2}\right) \cdot r$ & $p_{2} \cdot u(r)$ \\
\hline Personal consumption & $r+\left(1-p_{2}\right) \cdot r+p_{2} \cdot d$ & $p_{2} \cdot u(r-d)$ \\
\hline Quasi-public project & $r+\left(1-p_{2}\right)(r+x-d)$ & $u(y)+p_{2} \cdot u(r+x-d)$ \\
\hline
\end{tabular}

What is interesting about this comparison is that if the doctrine does not affect the probability of overthrowing the dictator-that is, if $p_{1}=p_{2}=p$ - the decision of the dictator as to whether to borrow to invest or borrow to consume does not depend on the regime. Whether or not the doctrine is in place, the dictator will borrow to invest rather than to consume if and only if (1-p) $x>d$. Although surprising at first, the logic is intuitive. Consider first the case with the doctrine. Compared to the case in which the dictator borrows for personal consumption, borrowing for investment provides an additional benefit of (1- $p) \cdot x$ to the dictator while imposing the (debt) cost of $d$. He bears the full cost of the debt because the banking community increases the repayment amount, from $d$ to $d /(1-p)$, to eliminate the risk of no repayment if the dictator is overthrown.

When the doctrine is not in place, by borrowing for personal consumption, the dictator is able to impose a negative externality onto the public if he is overthrown. The benefit to the dictator is $p . d$. If he borrows for investment, therefore, he must bear not only the cost of repayment, $(1-p) \cdot d$, but also this forgone opportunity. So the full cost of borrowing for investment is $d$. On the benefit side, he enjoys the additional cash flow of $x$ only when he is not overthrown. The dictator will therefore invest with the borrowed money if and only if (1-p).x is larger than $d$, which is the same as in the case with the doctrine.

What will be different between the two cases, however, is the probability of being overthrown at $t=3$ and the probability of a dictator coming into power at $\mathrm{t}=1$. With the doctrine, because the public has more to gain from overthrowing the dictator, it is more likely to overthrow than not. Conditional on $p$, the public's utility is strictly higher with the odious debt doctrine than without. Hence, it can be assumed that $p_{2}<p_{1}$ in equilibrium, so that $d /\left(1-p_{2}\right)<d /\left(1-p_{1}\right)$. Because the dictator now faces a different probability of being able to stay in power, his decision about whether to borrow to invest or to consume will also be different. Consider three possible cases. ${ }^{11}$

11. It is also possible that, within each regime, the dictator's choice between investment and personal consumption will affect the probability of overthrowing. For instance, with the doctrine, when the dictator borrows for personal consumption, the public, by overthrowing, gets the additional utility of $u(r)$. If the dictator invests, however, the public receives the additional utility of $u(x+r)$. Hence, investing can actually provide more incentive to the public to overthrow the dictatorial regime. However, our analysis on how the probabilities are different across the two regimes will not be affected. 
Case 1. If $x<d /\left(1-p_{2}\right)<d /\left(1-p_{1}\right)$, under both regimes, the dictator just borrows from abroad for his personal consumption. The dictator prefers the regime with no odious debt doctrine, $r+\left(1-p_{2}\right) \cdot r+p \cdot d>r+\left(1-p_{1}\right) \cdot r$, since, without the doctrine, not only can he impose a negative externality onto the successor government, but he is also more likely to stay in power at $\mathrm{t}=4$ because the public has a lower incentive to overthrow his government. The public realizes $p_{1} \cdot u(r)$ with the odious debt doctrine and $p_{2} \cdot u(r-d)$ without it. The public strictly prefers the imposition of the odious debt doctrine for the same reasons: it does not want to bear the negative externality imposed by the dictator, and it is more likely to set up a representative government at $\mathrm{t}=4$. Stepping back further, given that the dictator earns a higher utility under the regime without the odious debt doctrine, the dictator is more likely to attempt a coup at $\mathrm{t}=1$ when the odious debt doctrine is not in place.

Case 2. If $d /\left(1-p_{2}\right)<d /\left(1-p_{1}\right)<x$, the dictator makes the quasi-public investment under both regimes. The dictator realizes a higher expected utility under the regime without the odious debt doctrine: $r+\left(1-p_{2}\right)(r+x-d)>r+(1-$ $\left.p_{1}\right)\left(r+x-d /\left(1-p_{1}\right)\right)$. This is because (1) the dictator does not need to bear the full cost of debt and (2) he is more likely to stay in power without the odious debt doctrine. As for the public, since $p_{1}>p_{2}$ and $x+r>x+r-d$, it again strictly prefers the regime with the odious debt doctrine. It receives the positive externality from the dictator's investment without having to bear the debt cost and is more likely to overthrow the dictator at $\mathrm{t}=3$. Since the dictator realizes a higher expected utility without the odious debt doctrine, the probability of coup at $\mathrm{t}=1$ will be higher without the doctrine.

Case 3. When $d /\left(1-p_{2}\right)<x<d /\left(1-p_{1}\right)$, the dictator implements the quasi-public project when there is no odious debt doctrine but borrows for personal consumption when the doctrine is in place. The dictator expects utility of $r+(1-$ $\left.p_{2}\right)(r+x-d)$ without the doctrine and $r+\left(1-p_{1}\right) r$ with it. Since $p_{1}>p_{2}$ and $x-d>0$, the dictator prefers the scenario with no odious debt doctrine: $r+\left(1-p_{2}\right)(r+x-$ $d)>r+\left(1-p_{1}\right) \cdot r$. Without the doctrine, he can get the benefit of the investment and is less likely to be overthrown. The public's relative utility, on the other hand, is ambiguous. With the doctrine, the public earns $p_{1} \cdot u(r)$, whereas without, it earns $u(y)+p_{2} \cdot u(r+x-d)$. While the probability of having a representative government in $\mathrm{t}=4$ is higher $\left(p_{1}>p_{2}\right)$, the public does not receive the benefit of the quasipublic investment undertaken by the dictator $(u(r+x-d)>u(r))$. Particularly if $u(y)>0$, the public is more likely to be worse off with the doctrine than without. However, since the dictator realizes a higher utility with no odious debt doctrine, the dictator is more likely to stage a coup at $\mathrm{t}=1$.

These examples lead to a few generalizations: First, the dictator will always prefer the regime with no odious debt doctrine because it allows him to stay in power longer and gives him a higher expected utility from being in power, either through additional consumption that imposes a negative externality onto the public or through quasi-public investment. Thus, the odious debt doctrine makes the coup at $\mathrm{t}=1$ less likely. 
Second, on average, the odious debt doctrine makes it more difficult for the dictator to implement the quasi-public project. The dictator prefers to borrow for personal consumption instead. When the doctrine is in place, the dictator implements the project only in the second case.

Third, it is unclear whether the doctrine benefits the public. Conditional on the investment's being made or not, the doctrine increases the public's utility by (1) decreasing the probability that the dictator will stay in power, (2) decreasing the probability that a would-be dictator will come to power, and (3) either eliminating the negative externality imposed by the dictator's consumption or allowing the public to better enjoy the positive externality from the dictator's quasi-public investment. However, because the dictator is less likely to make the quasi-public investment under the doctrine, the public is less likely to be able to enjoy the fruits of such investment. Especially when $u(y)$ is large, the loss of (potential) benefit to the public will outweigh the gains.

\section{B. Empirical Premises}

In principle, the odious debt doctrine could be selectively applied to avoid harming the public. Consider case 3. With the doctrine, the dictator does not make the quasi-public investment. If the public's benefit from the investment is large, the doctrine should not be imposed, whereas, if small, it should. The determination should be based primarily on two factors: the size of the benefit, both tangible and intangible, to the public $(u(y)$ and $u(x-d))$ and the differential probability of overthrowing the dictatorial regime $\left(p_{1}\right.$ versus $\left.p_{2}\right)$. If $p_{1} \cdot u(r)>u(y)+p_{2} \cdot u(r+x-d)$, the doctrine should be imposed; otherwise, the doctrine should not be imposed. It is doubtful that decisionmakers can reliably perform these calculations on a case-by-case basis and possible that, in an aggregate sense, the inequality does not hold.

1. The Doctrine Will Deter Borrowing for Personal Consumption Without Interfering Excessively with Borrowing for Quasi-Public Investment that Benefits the Public.

Consider the empirical premises of this inequality. First, the variable $y$-the benefit the public receives from projects. Some of the literature implies that dictators frequently borrow money for the express purpose of building themselves unnecessary palaces. However, dictators generally become wealthy by taking kickbacks on public contracts and through similar forms of corruption. They build roads, airports, power plants, dams, and ports, and, although they skim off profits, the resulting infrastructure benefits the public, at least a little. ${ }^{12}$ For example, a government might use a loan to build a bridge or some other public project but would demand kickbacks from the contractor. If a $\$ 10$ million loan is used to build a $\$ 9$ million bridge, with government ministers skimming of the extra $\$ 1$ million, is this an odious debt? If so, the doctrine 
discourages an investment that could benefit the public; if not, the doctrine will have little effect on actual behavior. No doubt the dictators prefer this form of corruption because it gives them some political cover, but, by the same token, this form of corruption is not as bad as borrowing for personal consumption alone. Although there are well-known cases of prestige projects that yielded no gain to the public, ${ }^{13}$ most serious defenders of the odious debt doctrine do not argue that dictatorial governments should be deprived of credit for legitimate projects, even if they turn out to be failures.

During the past half century, numerous dictatorial regimes borrowed money from foreign creditors and made investments in infrastructure and industry, investments that have paid off for future generations. Chile under Augusto Pinochet, South Korea under Park Chung Hee, and Singapore under Lee Kwan Yew are classic development success stories. China's authoritarian regime has borrowed tremendous sums, and currently China is enjoying rapid economic growth. Even the authoritarian regimes that have been less successful in promoting economic growth cannot, in most cases, be accused of using foreign debt for personal consumption. The Latin American dictatorships, for example, did not squander their loans on consumption; they invested poorly. And even the worst kleptocratic dictators in Africa did not consume all of their loans. They used them mainly to pay off political supporters and to finance the army. ${ }^{14}$ All regimes must, to some extent, make transfer payments to keep domestic peace and to finance the army to protect the country from domestic unrest and foreign invasion; these types of payments are quasi-public investments because the public benefits from peace and domestic order.

Even more troublesome, straightforward borrowing for personal consumption is not necessarily harmful to the public. One cannot determine whether a particular debt is odious in isolation. Governments obtain funds from tax receipts and loans. There is no sense in which the two sources can be kept separate from each other. Thus, a dictator can evade the odious debt doctrine by arbitrarily designating bank loans as the source for public projects and tax revenue as the source for the dictator's consumption. The only way that the doctrine could limit borrowing would be if the dictator seeks to spend more money on himself than he could obtain from tax revenues alone. However, in nearly all realistic cases, extremely greedy dictators can satisfy themselves from tax revenues. By contrast, the original example of odious debt was a rare instance in which borrowed funds went directly into the pocket of the dictator. ${ }^{15}$

The main effect of the odious debt doctrine is to encourage dictators to be short-sighted. Because they are less likely to collect the return on investment,

13. See, e.g., ADAMS supra note 5, at 110-18 (describing projects that yielded little or no gain or turned out to be unneeded).

14. See ADAMS, supra note 5, at 110-31 (describing projects).

15. As Buchheit et al., supra note 4 , at 22 , observe, the modern defenders of the odious debt doctrine appear to defend a broader version of the rule, one that applies to any debt incurred by a dictator. A clear example is ADAMS, supra note 5 (discussing Tinoco). 
they are less likely to invest. If the odious debt doctrine increases the probability of being overthrown by a great enough amount, the dictator will borrow in order to consume rather than borrow in order to invest. In the limiting case, he will not invest at all. Although the public does not have to repay the debt for his consumption, it will also suffer from lower economic growth because he did not invest.

2. The Doctrine Will Substantially Increase the Probability that the Public Will Overthrow a Dictator and Replace Him with a Representative Government.

One might think that an argument in favor of the odious debt doctrine is that it increases the probability that the public will overthrow the dictator by offering the public debt relief if the attempt to overthrow succeeds. However, this argument ignores the way that the prospect of being overthrown affects the incentives of the dictator and hence public welfare. ${ }^{16}$ If the odious debt doctrine increases the risk of being overthrown, the dictator has less incentive to make quasi-public investments.

Ironically, the case for the odious debt doctrine is strongest if the doctrine has no effect on the probability that the dictator will be overthrown. If it has no effect, then the dictator's choice between investing and consuming will not be affected by whether the doctrine is in place. Thus, the only effect of the doctrine would be to release the public from debt if the overthrow occurs-a straightforward utility gain.

One might argue that this is in fact the case. Overthrowing a dictator is dangerous and risky, and the public is subject to a collective-action problem. In practice, the question for members of the public is whether to throw their support behind opponents of the dictator. The public can do so by engaging in strikes, protesting in the streets, and so forth. But these are highly costly actions-dictators typically react to them by torturing and murdering opponents - and so the incentive to free-ride will be high. And the public might expect that the opponents, when in power, will be no better than the dictator.

However, it is doubtful that the odious debt doctrine would have no effect on the probability of the dictator being overthrown. It is true that overthrowing a dictator is risky, but this is true whether or not the doctrine is in place. Given the background risks, debt release increases the reward. The doctrine ensures that the public has much to gain from the overthrow-debt relief-and the worse the dictator, the greater the benefit of overthrowing him. And typically revolutions against dictators are led by political entrepreneurs who will internalize some of the gains. 
3. The Doctrine Will Substantially Reduce the Probability that Would-Be Dictators Will Seek Power.

Although this premise might be correct, it does not necessarily lead to the conclusion that the odious debt doctrine will unambiguously benefit the public. Suppose, for the sake of argument, that having a representative government is always better than having a dictatorial regime, regardless of the dictator's choice between investment and consumption: $u(r)+u(r)$ is larger than both $p_{1} \cdot u(r)$ and $u(y)+p_{2} \cdot u(r+x-d)$. One might think that if would-be dictators are less likely to seek power because of the doctrine, the public will also be more likely to overthrow an authoritarian government with the doctrine than without.

If the odious debt doctrine makes the dictator more short-sighted and less likely to make quasi-public investment, even though the probability that a dictator might come into power is lower, the public is worse off if one does. The net welfare effect of the doctrine, therefore, will depend on how much worse off the public would be under a dictatorial regime and how much less likely aspiring dictators would be to seek power because of the doctrine.

4. If Applied Correctly, The Doctrine Will Reduce the Debt Burdens of Representative Governments.

It is not clear representative governments can afford to repudiate even odious debts. A government that repudiates debts, even with legal sanction, may be adjudged a high credit risk and refused further loans, or only given further loans at a high rate of interest. Thus, it is quite possible that the odious debt doctrine would have no effect on the debt burden of a post-dictatorial country.

Why might this be the case? Suppose there is some uncertainty about whether an existing government's loans will be subsequently treated as odious debt. Creditors might fear that, although the government is nominally a representative government, a later decisionmaker will determine that the representative institutions were not what they seemed and that power was exercised behind the scenes by a dictator. Suppose further that a future decisionmaker may be unable to determine whether loan proceeds were used to pay for a dictator's consumption or for a public project. Creditors will be unwilling to lend to this government.

Now, if the government seeks to maintain its creditworthiness, one way it can do so is by repaying the odious debts of the prior government. This will signal to creditors that future governments will behave in the same way, and this will resolve its concerns about lending to it. Another solution is to stipulate that the odious debt doctrine will apply to loans only after the regime has been designated odious by an international institution or important nations. ${ }^{17}$

17. Jayachandran \& Kremer, supra note 5, at 90-91. 
However, this requisite would significantly weaken the doctrine since international agreement on these matters is difficult to achieve. ${ }^{18}$

\section{A Comparison to Jayachandran and Kremer}

Jayachandran and Kremer provide a defense of the odious debt doctrine. ${ }^{19}$ In their model, as in ours, a would-be dictator moves first by seizing power or not seizing power. Next, the government (dictator or not) allocates resources to a productive activity (fruit-growing, in their example) or to an activity that benefits mainly the government (palace-building). The government can also authorize international trade in fruit, and can buy the inputs (marble) for palaces from foreign firms. Citizens are paid a wage whether they build palaces or harvest fruit, but, if resources are devoted to fruit-growing, they also benefit from the consumption of fruit. Productivity varies across time, and governments can borrow during productive years so they will have more funds during unproductive years.

Good governments will borrow in order to smooth citizens' consumption across time: that is, they borrow from foreign creditors during the unproductive year, use the money to buy fruit for citizens, and then pay back the loan during the productive year, when the excess harvest is sold internationally. Bad governments will borrow in order to ensure palace production during unproductive years; they leave office and subsequent populations must repay the loan.

In the absence of the odious debt doctrine, there is a reputational equilibrium in which all creditors are repaid, whether or not the debt was odious, because they have a credible threat to sue a government that defaults. If a government defaults, creditors bring suit in a country in which the government has assets. Domestic and international law provides that, indeed, the assets of the debtor country can be seized by creditors. The odious debt doctrine provides that the creditors cannot seize the assets of the debtor in the creditors' countries if the debtor is a successor government to a dictatorship that used the borrowed funds to enrich the rulers rather than to benefit the public.

Under these assumptions, Jayachandran and Kremer show that the odious debt doctrine improves the welfare of the affected population. Specifically, the doctrine destroys the reputational equilibrium in which a successor government voluntarily repays the odious debt incurred by the previous dictatorial regime. In equilibrium, creditors lend to nonodious governments and refuse to lend to dictators, and this reduces the incentive of would-be dictators to take power in the first place. The reduced probability of a dictatorship benefits the public. And even if dictators come to power, they are prevented from borrowing

19. Jayachandran \& Kremer, supra note 5. 
money to build palaces and so cannot force a future generation to pay interest on a loan that does not benefit the public.

Jayachandran and Kremer's model differs from ours in three main ways. First, it does not permit the dictator to make a quasi-public investment. Dictators can only consume, that is, build a palace at the expense of growing fruit, with the borrowed money. As a result, dictators' activities are unambiguously bad. As demonstrated above, ${ }^{20}$ this assumption is unrealistic. Dictators build roads to transport troops that the public can use as well. Dictators build better mechanisms to extract natural resources that benefit later generations. Dictators fight insurgents who injure civilians as well as threaten the security of the dictatorship. Thus, Jayachandran and Kremer's model is biased in favor of shutting off credit. They acknowledge that the odious debt doctrine is attractive only if it is "applied against regimes that are borrowing against the people's interests," ${ }^{21}$ but they fail to acknowledge that the assumption about the absence of quasi-public investments is unrealistic.

Second, Jayachandran and Kremer assume that the dictator is always overthrown after one period: the probability of being overthrown is one. This assumption also biases the dictator's incentives in favor of short-term consumption rather than long-term investment because the dictator cannot enjoy any of the returns from the investment. In our model, the dictator has only a risk of being overthrown. If he invests, he has a chance of obtaining a return, and that return motivates the dictator's investment. In our model, the sole reason the dictator would want to invest in a project is to be able to build an even bigger palace tomorrow. But, if the dictator is thrown out before the palace is built, the public may be able to enjoy the returns on that investment. Furthermore, if the investment itself has some benefit to the public that the dictator cannot capture, $u(y)>0$, trying to provide incentives to the dictator to favor that quasi-public investment may be beneficial to the public.

Third, Jayachandran and Kremer focus on comparing loan and trade sanctions, which our model does not explicitly analyze. Jayachandran and Kremer argue that the historic weakness of trade sanctions should not discourage the adoption of a system of loan sanctions because their model shows that loan sanctions are more likely to work and have better welfare properties than trade sanctions do. However, this argument is problematic.

Jayachandran and Kremer assume that loan sanctions are enforceable because creditors can collect in only one or a limited number of countries, whereas odious governments can trade with people in any state. ${ }^{22}$ Thus, the collective action problem in enforcing trade sanctions is greater than the collective-action problem in enforcing loan sanctions. This claim is important for Jayachandran and Kremer because they acknowledge that trade sanctions

20. See generally supra Part III.A.3.

21. Jayachandran \& Kremer, supra note 5, at 89.

22. Note that on the assumption that mere reputation is not sufficient to support sovereign borrowing, there must be an additional sanction, such as loss of assets. 
have been unsatisfactory. ${ }^{23}$ The problem with this argument is that governments can choose not to place assets in, or can choose to withdraw assets from, countries that will not make them available to creditors if the governments default. Thus, if the United States and the European Union adopted the odious debt doctrine, then new dictatorships would remove their assets from these countries and place them in other countries, which would be happy to take them in return for a fee or other diplomatic benefits. Western investors could easily invest in firms operating in those countries, which in turn would lend to the odious dictators. The collective action problem is identical to that in the trade area, unless only a small number of countries can be trusted to hold assets and dispose of them properly. This is unlikely, and in any event similar limitations apply to trade-for example, only certain countries are reliable suppliers of marble, et cetera.

In addition, the superior welfare benefits of loan sanctions are also driven by an assumption that a dictator will not respond to loan sanctions by selling more nonrenewable resources to the international market. Jayachandran and Kremer admit as much in a footnote ${ }^{24}$ but do not acknowledge the importance of this fact. History shows that odious regimes typically sell nonrenewable resources such as oil (Nigeria) and diamonds (Sierra Leone). If a dictatorial regime cannot borrow because of the odious debt doctrine, the regime might attempt to extract and sell inefficiently large quantities of nonrenewable natural resources to build a palace, whereas, with a trade sanction but no loan sanction, there may be less depletion, benefiting the future population.

There is no reason to think loan sanctions are superior to trade sanctions. If loan sanctions are applied routinely, then states will withdraw assets from the states in which they would otherwise store the assets. There may be limits on the extent to which states can do this, but there is also no reason to think that depriving dictatorships of places to store assets is any more or less effective a type of sanction than other forms of diplomatic pressure or use of resources (such as withdrawal of foreign aid).

IV

\section{A NOTE ON EXTERNAL BENEFITS FROM COOPERATING WITH DICTATORS}

Foreign powers, including western powers, have frequently cooperated with dictators rather than isolate them. Cooperation has had many motivations. First, many dictators preside over long-suffering populations. In many instances, a dictator is the cause of the population's suffering, but in many other cases he is not. A western government that seeks to aid a population wracked by famine, drought, disease, economic distress, ethnic conflict, and so forth

23. The literature on trade sanctions is substantial, and the evidence of their effectiveness is mixed and hard to summarize. The classic monograph on the topic is HUFBAUER, supra note 3, at 92-93 (finding thirty-four-percent success rate in 116 postwar cases).

24. Jayachandran \& Kremer, supra note 5 , at 88 n.7. 
almost always must work through the government, even if it is a dictatorship. Dictatorial governments frequently condition access to the populations on payments to the government itself-or simply structure or control the aid distribution in a way to ensure that it receives a portion. Donors face a difficult choice, and many rationally bribe the dictator, or tolerate kickbacks and other forms of corruption that benefit the dictator, so he will allow them to help his population. ${ }^{25}$

Second, many dictators control states that have strategic value or that are simply too important to ignore. During the Cold War, the United States and other western powers frequently felt they had to support dictators in order to limit the spread of Soviet influence. ${ }^{26}$ Today, the United States makes use of dictators to help track down terrorists, control drug smugglers, resolve conflicts, and provide military bases. Dictators must always be bribed, in cash or in kind, for their support.

A western government can bribe dictators in many ways. It can give them cash payments, and this is done frequently. It can give them technical assistance or military support. It can offer favorable terms of trade. And it can offer credit or access to credit. Obviously, offering credit is inconsistent with the odious debt rule. But it would be odd to deny credit under the odious debt rule while engaging in other types of transfers. Isolating dictators is frequently not a viable strategy-because it just leads to greater suffering for the population or interferes with other important strategic interests. As long as this is the case, there is no reason to single out credit for restriction.

The larger point is that international relations are fluid; governments need flexibility to deal with dictators. One could at least imagine a legal regime that required isolation of dictators; if states stuck by it, at least it would have a meaningful effect. Or one could continue with the current regime, under which pressure is exerted in an episodic fashion and mainly against states that are not of strategic value to western powers. But a regime that singles out credit while preserving all other forms of cooperation, including aid, makes no sense at all.

The need for flexibility in regulating access to credit can be seen by comparing loan sanctions with trade sanctions. Hufbauer and his coauthors' empirical survey suggested that trade sanctions tend to work only when certain conditions are satisfied: (1) the target must be relatively weak, and the goals must be relatively limited; (2) many states participate; (3) the target must be an ally or have some friendly relationship with the state that imposes the sanctions; (4) the sanctions must be applied quickly rather than incrementally; and (5) the sanctions cannot be too costly for the sanctioning country. ${ }^{27}$ If this is true for trade, it is surely true for loan sanctions. But because the odious debt doctrine

25. For numerous examples, see ADAMS, supra note 5.

26. See OdD ARne Westad, The Global Cold WAR: THIRD World InTERVEnTIONS AND THE MAKING OF OUR TIMES (2005).

27. HUFBAUER, supra note 3 , at 94-105. 
does not incorporate these factors - and how could one have a legal rule that is applied only against the weak?-it is not likely to work as intended.

A final problem is that efforts to pressure dictators can be undermined by geopolitical rivalries. For example, current western efforts to pressure Sudan to halt the genocide in Darfur are being undermined by China, which purchases Sudanese oil and seeks to enhance its influence in Africa. ${ }^{28}$ Rivalries of this kind have been a common problem for trade sanctions and are likely to be a problem for loan sanctions as well. The frequent lack of international agreement about whether a dictator should be pressured provides grounds for skepticism about Jayachandran and Kremer's proposal that an international organization have the authority to declare when a regime is officially odious. ${ }^{29}$

\section{$\mathrm{V}$ \\ CONCLUSION}

Loan sanctions pressure dictators to give up power and may deter would-be dictators from taking power in the first place, but they also harm the dictatorship's public when dictators are not deterred, and they interfere with diplomatic efforts to obtain cooperation from dictators in matters of general interest. The odious debt doctrine as currently formulated and defended does not take account of all morally relevant factors.

The traditional backward-looking defense of the odious debt doctrine, which suggests that the doctrine is costless because it releases a suffering population from an unjust debt, is seriously incomplete. Our model makes clear that because the dictator controls the government, the doctrine necessarily harms the public if it is to affect the incentives of the dictator. Although in specific cases the benefits of loan sanctions may exceed the costs, the defenders of the doctrine have not made the empirical case that the net benefits are sufficiently high in the aggregate as to warrant routine application of loan sanctions to odious dictators. In the absence of such a showing, there is no reason to think that the odious debt doctrine would be a desirable rule of international law.

28. See, e.g., BBC News, Chinese Leader Boosts Sudan Ties, Feb. 2, 2007, http://news.bbc.co.uk/2/ hi/africa/6323017.stm (last visited Oct. 2, 2007).

29. They propose this institution in order to reduce uncertainty, so creditors will not refrain from lending to a deserving nation for fear that it will subsequently be declared odious. See also Seema Jayachandran, Michael Kremer \& Jonathan Shafter, Applying the Odious Debts Doctrine While Preserving Legitimate Lending, ETHICS \& INT'L AFF. (2006). For reasons given in the text, we are skeptical about the viability of such an institution. On this problem, see Paul B. Stephan, The Institutionalist Implications of an Odious Debt Doctrine, 70 LAW \& CONTEMP. PROBS. 213 (Summer 2007). 